NyS udkommer to gange om året.

Du kan tegne abonnement eller bestille

enkeltnumre ved at henvende dig til:

Dansk Sprognævn

nys.abo@dsn.dk

Gamle numre er tilgængelige på www.nys.dk

\title{
Bidrag til NyS
}

Har du lyst til at indsende en artikel, en anmeldelse, et debatindlæg eller andet, så kontakt redaktionen:

nys.red@dsn.dk

NyS-redaktionen

Københavns Universitet

Emil Holms Kanal 2

2300 København S

Oplysninger om formater mv. kan findes på www.nys.dk/information/authors 